\title{
The Heterogenous Impact of Taxation on FDI: A Note on Djankov et al. (2010)*
}

Alejandro Esteller-Moré (Universitat de Barcelona \& IEB), Leonzio Rizzo (Università di Ferrara \& IEB)**, Riccardo Secomandi (Università di Ferrara \& Università di Parma)

Summary. Taxes in the host country matter a lot for FDI inflows, but only for non-OECD countries. Taking advantage of the rich dataset constructed by Djankov et al. (2010), we show, for example, that raising the first-year effective corporate income tax rate by $10 \mathrm{pp}$ reduces FDI inflows by 3.4 to $1.9 \mathrm{pp}$ in non-OECD countries; and the effect is null for OECD countries. Not taking this heterogeneity into account upward (downward) biases the estimated impact of the corporate tax on FDI inflows for OECD (non-OECD) countries.

Keywords: Foreign direct investment; corporate income tax rate; OECD.

JEL Codes: E22; F23; G31; H25; H32; L26.

* The authors acknowledge funding from the Ministerio de Economía y Competitividad/FEDER [RTI2018095983-B-I00], and Esteller-Moré also from Generalitat de Catalunya [2017SGR796].

** Corresponding author at: Via degli Adelardi 33, 44121 Ferrara, Italy, E-mail address: leonzio.rizzo@unife.it 


\section{Introduction}

Using a dataset of 85 countries in 2004, Djankov et al. (2010) (from now on, DGMRS) study the impact of the corporate income tax on firm investment, foreign direct investment (FDI) and entrepreneurial activity. Tax data come from a rich survey conducted jointly by the authors and PricewaterhouseCoopers. From a cross-country standardized domestic firm, so-called TaxpayerCo, they compute effective corporate tax rates in each nation. As such a standard firm is new, they also compute a five-year-effective corporate tax rate, which allows taking into account the impact of assets' depreciation. They also compute an effective labor tax rate payable by TaxpayerCo, and another one for the sum of property taxes, business license taxes, financial transactions, and asset and capital taxes also payable by TaxpayerCo. In addition, they have information about tax burden measure at the country level (Doing Business data, World Bank): the annual number of tax payments.

As outcome measures, according to the objective of their analysis, they use gross fixed capital formation, the number of business establishments and the rate of new business registrations as proxies of entrepreneurship, and the net inflow of FDI in each country. These net foreign inflows are aimed at acquiring a lasting management interest of a given firm (ten percent or more of voting stock) in the host country.

\section{INSERT HERE FIGURE 1}

For all these outcome measures, and independently of which corporate tax rate is used, the corporate tax exerts a negative impact. In general, results are robust to the inclusion of different sets of controls. In this Note, we will exclusively focus on the impact of taxes on FDI using the same empirical methodology and the same rich dataset of DGMRS, but testing for the presence of heterogeneity.

According to the correlations shown in Figure 1, results seem to be exclusively driven by non-OECD countries. This is the hypothesis we want to test in this Note, which would have important policy implications. That is why, we re-run all FDI regressions of the DGMRS's paper accounting for a potential different impact between $O E C D$ and non-OECD countries. A regression analysis distinguishing between OECD and non-OECD countries confirms corporate taxes matter a lot for investment, but not for OECD countries. Thus, any specific calculation of the impact of taxes on FDI within the OECD (see, e.g., Skeie, 2017) should be aware of this.

\section{From an aggregate to a disaggregate specification: OECD vs non-OECD countries}

Regarding FDI, DGMRS carry out five triples of regressions with different sets of controls. A $10 \%$ increase of the statutory corporate tax rate decreases the percentage of FDI over GDP by a magnitude ranging from 2 to $1.1 \mathrm{pp}$ depending on the specification. They estimate similar impacts for the first-year effective corporate tax rate, ranging from 2.3 to $1.7 \mathrm{pp}$, and for the five-year effective corporate tax rate, from 2.4 to $1.7 \mathrm{pp}$. These are noticeable reactions.

First of all, we replicate DGMRS' s regressions without controls (Table 1). In particular, column (1) replicates DGMRS's original basic result using the statutory corporate tax rate. In column (2), using that tax rate, we test for a heterogeneous response: non-OECD response is statistically significant and negative, -0.372 , while 
the response of $\mathrm{OECD}$ countries is still negative, -0.04 (i.e., $-0.372+0.332$ ), but cannot disregard it is null. In column (3) and in column (5), again, we replicate their original results for the first-year effective tax rate and for the five-year effective tax rate, respectively, while in column (4) and in column (6), we test for the existence of heterogeneous responses using each one of those alternative tax rates. FDI flows are only affected by taxes for non-OECD countries, being then the response almost twofold the originally estimated by DGMRS.

We obtain similar results by including tax controls, as shown in Table 2; the structure of the table by columns is identical to Table 1. As DGMRS, we find a negative impact of personal income top marginal tax rate, but only for non-OECD; thus, again the original aggregate estimated impact was hiding a null impact for OECD countries and a much stronger one for non-OECD countries.

\section{INSERT HERE TABLE 2}

In Table 3, we control for the complexity of the tax administration procedures and for the existence of tax evasion, again as DGMRS did. In this case, we lose 22 observations ( 20 for non-OECD countries) out of 84 , because the variable tax evasion is not available for all countries. Heterogeneity results hold again, although the precision of the estimates of the interaction diminishes. As in DGMRS, evasion - probably as a proxy of a light tax enforcement policy - has a positive impact on FDI inflows, and cannot disregard in all cases it has no impact for OECD countries. This is also an interesting result. The variables that have to do with the complexity of the tax system, though, do not have a statistically significant impact in any case.

\section{INSERT HERE TABLE 3}

We finally, in Table 4, control for democracy indices, GDP per capita and employment rigidity as DGMRS also did. Heterogeneity emerges again. Within non-OECD countries, the higher the level of GDP per capita, the larger the level of FDI inflows. For OECD countries, though, this positive impact of GDP per capita tends to cancel; probably, for those relatively richer countries, the benefits of a higher GDP per capita have reached a bliss point. In any case, what is important for this Note is that independently of the set of controls (including GDP per capita), heterogeneity remains such that corporate income taxes do only have an impact for non-OECD countries.

\section{INSERT HERE TABLE 4}

\section{Conclusions}

What are the factors that might drive this heterogeneity? During the period of analysis, 2003-2005, the OECD market can be considered as market-friendly as to the implementation of international cooperation measures (OECD, 2019a). In particular, this kind of measures ease market freedom eliminating anticompetitive barriers. Interestingly, a strand of the literature shows the quality of institutions matters for attracting FDI (McCloud and Kumbhakar, 2012; or Dort et al., 2014). World Governance Indicators regulatory quality, political stability, control of corruption, voice and accountability, rule of law, and government effectiveness - show that, on average, OECD countries have a higher level of institutional quality than non-OECD countries. In accordance with this, when we include in the regression a dummy accounting for high level of institutional quality (equal to 1 when the corresponding indicator is above the median, 0 otherwise), its interaction with the corporate tax rate is positive in all cases, but only statistically significant for "voice and accountability". Thus, this proxy of institutional quality seems a key institutional factor for FDI inflows. In fact, using this proxy to differentiate across countries according to their level of 
institutional quality, we obtain very similar results to those differentiating between OECD and non-OECD countries $^{1}$. All in all, it seems that the institutional context plays a key role at explaining to what extent taxes matter or not at directing FDI flows.

Additionally, all OECD countries agreed on a OECD Model Tax Convention (OECD, 2019b). This is the basis for negotiation and application of bilateral tax treaties between countries, designed to assist business while helping to prevent tax evasion and avoidance. The OECD Model also provides a means for settling on a uniform basis the most common problems that arise in the field of international double taxation. When the OECD published its first Draft Model Tax Convention in 1963, only a few dozen tax agreements were in force. Since that time, the OECD Model Tax Convention has facilitated bilateral negotiations between countries and made possible a desirable harmonization for the benefit of both taxpayers and national administrations. Since then on, the tax conventions between OECD countries increased sharply. In 2005, on average the number of bilateral treaties per OECD country was 65 , and this average was 25 for non-OECD countries. Undoubtedly, this might also make a difference in how sensitive FDI flows are to level of taxes in the host country.

Apart from taxes, there are other important FDI determinants highlighted by the literature like labor market regulations (Botero et al., 2004), enforcement of property rights (Acemoglu et al., 2002), or shareholder protection (La Porta et al., 1999). It might be very likely that our non -monotone finding for OECD vs non-OECD countries will also hold for these other determinants. We leave this interesting issue for further research.

\section{Acknowledgements}

We are grateful for the comments received by an anonymous referee.

\section{References}

Acemoglu, D., Johnson, S. and Robinson, J. (2002), "Reversal of Fortune: Geography and Institutions in the Making of the Modern World Income Distribution", Quarterly Journal of Economics, 117, 4, 1231-1294, https://doi.org/10.1162/003355302320935025

Botero J., Djankov, S., La Porta, R., López de-Silanes, F. and Shleifer A. (2004), "The regulation of Labor", Quarterly Journal of Economics, 119, 4, 1939-1382, https://doi.org/10.1162/0033553042476215

Djankov, S., Ganser, T., McLiesh, C., Ramalho, R., and Shleifer, A. (2010): "The Effect of Corporate Taxes on Investment and Entrepreneurship", American Economic Journal: Macroeconomics, 2, 3, 31-64, https://doi.org/10.1257/mac.2.3.31

Dort, T., Méon, P.G., and Sekkat, K. (2014), "Does Investment Spur Growth Everywhere? Not Where Institutions Are Weak", Kyklos, Wiley Blackwell, 67, 4, 482-505, https://doi.org/10.1111/kykl.12064

La Porta R., Lopez-de-Silanes, F., Shleifer, A., and Vishny, R. (2000), "Investor protection and corporate governance", Journal of Financial Economics, 58, 1, 1-2, 3-27, https://doi.org/10.1016/S0304405X(00)00065-9

\footnotetext{
${ }^{1}$ Results of the regressions are available upon request
} 
McCloud, N., and Kumbhakar, S.C. (2012), "Institutions, foreign direct investment and growth: a hierarchical Bayesian approach", J. R. Statist. Soc. A, 175, 1, 83-105,

https://www.jstor.org/stable/41409709

Skeie, $\varnothing$. В. (2017), "International Differences in Corporate Taxation, Foreign Direct Investment and Tax Revenues", Economics Department Working Paper No. 1359, OECD, Paris, https://doi.org/10.1787/ddd8669b-en

\section{Web references}

OECD (2019a). Recommendations and Guidelines on Regulatory Policy - OECD. [online] Available at: https://www.oecd.org/regreform/regulatory-policy/recommendations-guidelines.htm [Accessed 3 Aug. 2019].

OECD (2019b). Tax treaties: update to OECD Model Tax Convention released - OECD. [online] Available at: https://www.oecd.org/ctp/tax-treaties-2017-update-to-oecd-model-tax-convention-released.htm [Accessed 3 Aug. 2019]. 
Figure 1: Relationship between FDI and tax rates in OECD vs non-OECD countries.

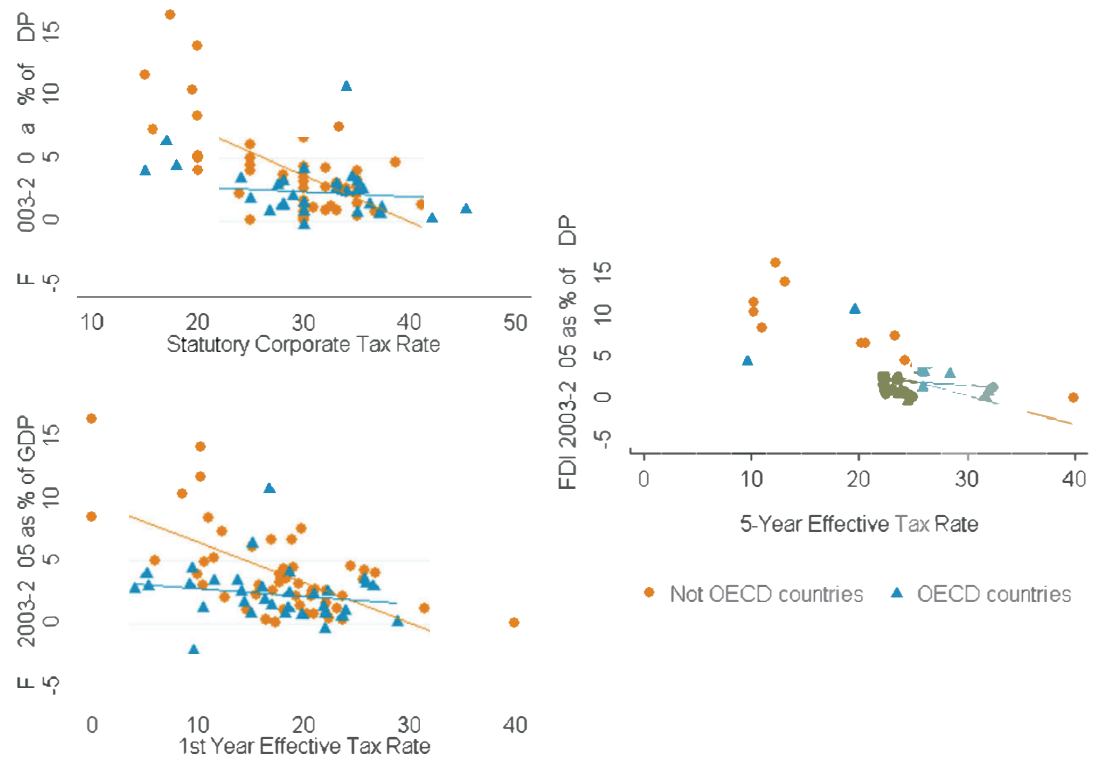

Source: Djankov et al.'s (2010) data.

Table 1: FDI regressions without controls.

\begin{tabular}{|c|c|c|c|c|c|c|}
\hline & $\begin{array}{c}(1) \\
\text { FDI/GDP } \\
\text { DGMRS }\end{array}$ & $\begin{array}{c}\text { (2) } \\
\text { FDI/GDP OECD }\end{array}$ & $\begin{array}{c}(3) \\
\text { FDI/GDP } \\
\text { DGMRS }\end{array}$ & $\begin{array}{c}\text { (4) } \\
\text { FDI/GDP OECD }\end{array}$ & $\begin{array}{c}\text { (5) } \\
\text { FDI/GDP } \\
\text { DGMRS }\end{array}$ & $\begin{array}{c}\text { (6) } \\
\text { FDI/GDP OECD }\end{array}$ \\
\hline Statutory Corporate Tax Rate & $\begin{array}{c}-0.195^{* * *} \\
(0.046)\end{array}$ & $\begin{array}{c}-0.372^{* * *} \\
(0.060)\end{array}$ & & & & \\
\hline $\begin{array}{l}\text { Statutory Corporate tax Rate } \\
\times \text { OECD }\end{array}$ & & $\begin{array}{c}0.332^{* * *} \\
(0.082)\end{array}$ & & & & \\
\hline 1st Year Effective Tax Rate & & & $\begin{array}{c}-0.225 * * * \\
(0.045)\end{array}$ & $\begin{array}{c}-0.324 * * * \\
(0.051)\end{array}$ & & \\
\hline $\begin{array}{l}\text { 1st Year Effective Tax Rate } \times \\
\text { OECD }\end{array}$ & & & & $\begin{array}{c}0.261^{* * *} \\
(0.087)\end{array}$ & & \\
\hline 5-Year Effective Tax Rate & & & & & $\begin{array}{c}-0.223^{* * *} \\
(0.050)\end{array}$ & $\begin{array}{c}-0.357^{* * *} \\
(0.060)\end{array}$ \\
\hline $\begin{array}{l}\text { 5-Year Effective Tax Rate } \times \\
\text { OECD }\end{array}$ & & & & & & $\begin{array}{c}0.289 * * * \\
(0.092)\end{array}$ \\
\hline OECD & & $\begin{array}{c}-11.239 * * * \\
(2.452)\end{array}$ & & $\begin{array}{c}-6.260 * * * \\
(1.599)\end{array}$ & & $\begin{array}{c}-7.403^{* * *} \\
(1.870)\end{array}$ \\
\hline Constant & $\begin{array}{c}9.044 * * * \\
(1.378)\end{array}$ & $\begin{array}{c}14.801^{* * *} \\
(1.774)\end{array}$ & $\begin{array}{l}7.291 * * * \\
(0.845)\end{array}$ & $\begin{array}{c}9.724^{* * *} \\
(0.975)\end{array}$ & $\begin{array}{c}7.717^{* * *} \\
(1.023)\end{array}$ & $\begin{array}{c}11.093^{* * *} \\
(1.246)\end{array}$ \\
\hline Observations & 84 & 84 & 84 & 84 & 84 & 84 \\
\hline $\begin{array}{l}\text { R-squared } \\
\text { Standard errors in parentheses } \\
{ }^{* * *} p<0.01,{ }^{* *} p<0.05,{ }^{*} p<0.1\end{array}$ & 0.180 & 0.370 & 0.232 & 0.378 & 0.196 & 0.355 \\
\hline
\end{tabular}


Table 2: FDI regressions with tax controls.

\begin{tabular}{|c|c|c|c|c|c|c|}
\hline & $\begin{array}{l}(1) \\
\text { FDI/GDP } \\
D G M R S\end{array}$ & $\begin{array}{c}\text { (2) } \\
\text { FDI/GDP OECD }\end{array}$ & $\begin{array}{l}\text { (3) } \\
\text { FDI/GDP } \\
\text { DGMRS }\end{array}$ & $\begin{array}{c}(4) \\
F D I / G D P O E C D\end{array}$ & $\begin{array}{l}(5) \\
\text { FDI/GDP } \\
D G M R S\end{array}$ & $\begin{array}{c}(6) \\
\text { FDI/GDP OECD }\end{array}$ \\
\hline Statutory Corporate Tax Rate & $\begin{array}{c}-0.166^{* * *} \\
(0.048)\end{array}$ & $\begin{array}{c}-0.315^{* * *} \\
(0.065)\end{array}$ & & & & \\
\hline Statutory Corporate Tax Rate $\times \mathrm{OECD}$ & & $\begin{array}{c}0.282^{* * *} \\
(0.094)\end{array}$ & & & & \\
\hline 1st Year Effective Tax Rate & & & $\begin{array}{c}-0.225 * * * \\
(0.048)\end{array}$ & $\begin{array}{c}-0.344^{* * *} \\
(0.054)\end{array}$ & & \\
\hline 1st Year Effective Tax Rate $\times \mathrm{OECD}$ & & & & $\begin{array}{c}0.282^{* * *} \\
(0.099)\end{array}$ & & \\
\hline 5-Year Effective Tax Rate & & & & & $\begin{array}{c}-0.238^{* * *} \\
(0.053)\end{array}$ & $\begin{array}{c}-0.378^{* * *} \\
(0.063)\end{array}$ \\
\hline 5-Year Effective Tax Rate $\times$ OECD & & & & & & $\begin{array}{c}0.308^{* * *} \\
(0.105)\end{array}$ \\
\hline Other Taxes & $\begin{array}{l}-0.127 \\
(0.113)\end{array}$ & $\begin{array}{l}-0.180 \\
(0.110)\end{array}$ & $\begin{array}{c}0.019 \\
(0.116)\end{array}$ & $\begin{array}{c}0.078 \\
(0.115)\end{array}$ & $\begin{array}{c}0.012 \\
(0.116)\end{array}$ & $\begin{array}{c}0.046 \\
(0.115)\end{array}$ \\
\hline VAT and Sales Tax & $\begin{array}{l}-0.064^{*} \\
(0.038)\end{array}$ & $\begin{array}{l}-0.050 \\
(0.038)\end{array}$ & $\begin{array}{c}-0.079 * * \\
(0.036)\end{array}$ & $\begin{array}{c}-0.088^{* *} \\
(0.034)\end{array}$ & $\begin{array}{c}-0.097 * * * \\
(0.037)\end{array}$ & $\begin{array}{c}-0.108^{* * *} \\
(0.035)\end{array}$ \\
\hline PIT top marginal rate & $\begin{array}{l}-0.047 \\
(0.029)\end{array}$ & $\begin{array}{l}-0.047 \\
(0.036)\end{array}$ & $\begin{array}{c}-0.056^{* *} \\
(0.026)\end{array}$ & $\begin{array}{c}-0.107^{* * *} \\
(0.032)\end{array}$ & $\begin{array}{c}-0.059 * * \\
(0.027)\end{array}$ & $\begin{array}{c}-0.098^{* * *} \\
(0.032)\end{array}$ \\
\hline Other Taxes $\times$ OECD & & $\begin{array}{c}0.337 \\
(0.345)\end{array}$ & & $\begin{array}{c}0.045 \\
(0.320)\end{array}$ & & $\begin{array}{c}0.124 \\
(0.328)\end{array}$ \\
\hline VAT and Sales Tax $\times$ OECD & & $\begin{array}{c}0.102 \\
(0.107)\end{array}$ & & $\begin{array}{c}0.129 \\
(0.100)\end{array}$ & & $\begin{array}{c}0.135 \\
(0.108)\end{array}$ \\
\hline PIT top marginal rate $\times \mathrm{OECD}$ & & $\begin{array}{c}0.055 \\
(0.058)\end{array}$ & & $\begin{array}{l}0.124^{* *} \\
(0.055)\end{array}$ & & $\begin{array}{l}0.112^{* *} \\
(0.054)\end{array}$ \\
\hline OECD & & $\begin{array}{c}-13.812^{* * *} \\
(3.502)\end{array}$ & & $\begin{array}{c}-12.693^{* * *} \\
(2.791)\end{array}$ & & $\begin{array}{c}-13.670^{* * *} \\
(3.209)\end{array}$ \\
\hline Constant & $\begin{array}{c}11.078^{* * *} \\
(1.588)\end{array}$ & $\begin{array}{c}15.831^{* * *} \\
(1.881)\end{array}$ & $\begin{array}{c}10.488^{* * *} \\
(1.294)\end{array}$ & $\begin{array}{c}14.672^{* * *} \\
(1.475)\end{array}$ & $\begin{array}{c}11.622^{* * *} \\
(1.464)\end{array}$ & $\begin{array}{c}16.206^{* * *} \\
(1.684)\end{array}$ \\
\hline Observations & 84 & 84 & 84 & 84 & 84 & 84 \\
\hline $\begin{array}{l}\text { R-squared } \\
\text { Standard errors in parentheses } \\
{ }_{* * *} p<0.01,{ }^{* *} p<0.05,{ }^{*} p<0.1\end{array}$ & 0.245 & 0.420 & 0.320 & 0.504 & 0.308 & 0.488 \\
\hline
\end{tabular}


Table 3: FDI regressions with tax complexity controls.

$\begin{array}{llllll}1 & \text { (1) }\end{array}$

FDI/GDP FDI/GDP FDI/GDP

DGMRS FDI/GDP OECD DGMRS FDI/GDPOECD DGMRS FDI/GDP OECD

$\begin{array}{lcc}\text { Statutory Corporate Tax Rate } & -0.177^{* * *} & -0.277^{* * *} \\ \text { Statutory Corporate Tax Rate } \times \text { OECD } & (0.055) & (0.098) \\ & & 0.240^{* *} \\ & & (0.111)\end{array}$

1st Year Effective Tax Rate

$\begin{array}{cc}-0.209 * * * & -0.193 * * \\ (0.056) & (0.075) \\ & 0.129 \\ & (0.102)\end{array}$

5-Year Effective Tax Rate

5-Year Effective Tax Rate $\times$ OECD

Log of number of tax payments

$0.351-0.81$

$(0.862)$

0.511

$-1.006$

$-0.197^{* * *} \quad-0.214^{* * *}$

(0.061) (0.080)

(0.568)

(0.862)

(0.557)

(0.859)

0.139

$1.014^{* *}$

$1.372^{* *}$

$0.987 * *$

1.332*

(0.106)

Tax evasion

(0.444)

(0.656)

(0.432)

(0.668)

$-1.207$

Procedures to start a business

0.083

$-0.179$

0.090

$-0.188$

(0.124)

(0.179)

0.456

(0.843)

(0.128)

(0.178)

0.874

(1.095)

1.101

(0.570)

$1.405^{* *}$

Log of number of tax payments $\times$ OECD

$-1.429 *$

(1.096)

1.109**

(0.656)

Tax evasion $\times$ OECD

(0.799)

$-1.320$

(0.446)

$-0.239$

0.135

(0.820)

0.071

(0.176)

(0.232)

0.142

(0.127)

1.278

(1.081)

$-1.333$

(0.815)

0.185

(0.233)

(0.230)

$-9.019$

$-5.865$

$-7.479$

(6.952)

(6.667)

(6.768)

Constant

2.955

$12.885^{* *}$

1.036

9.369

1.140

11.223*

Observations

(3.452)

(6.172)

(3.166)

(5.909)

(3.269)

(6.021)

62

62

62

62

62

62

R-squared

0.220

0.551

0.261

0.543

0.223

0.550

Standard errors in parentheses

${ }^{* * *} p<0.01,{ }^{* *} p<0.05,{ }^{*} p<0.1$

Notes: columns (1), (3) and (5) contain results of the regressions on FDI of Djankov et al.'s (2010) paper. Columns (2), (4) and (6) include regressions on FDI where all coefficients of the independent variables are interacted with a dummy which equals to 1 if the country belongs to the OECD and 0 otherwise. 
Table 4: FDI regressions with democracy, GDP per capita and employment rigidity controls.

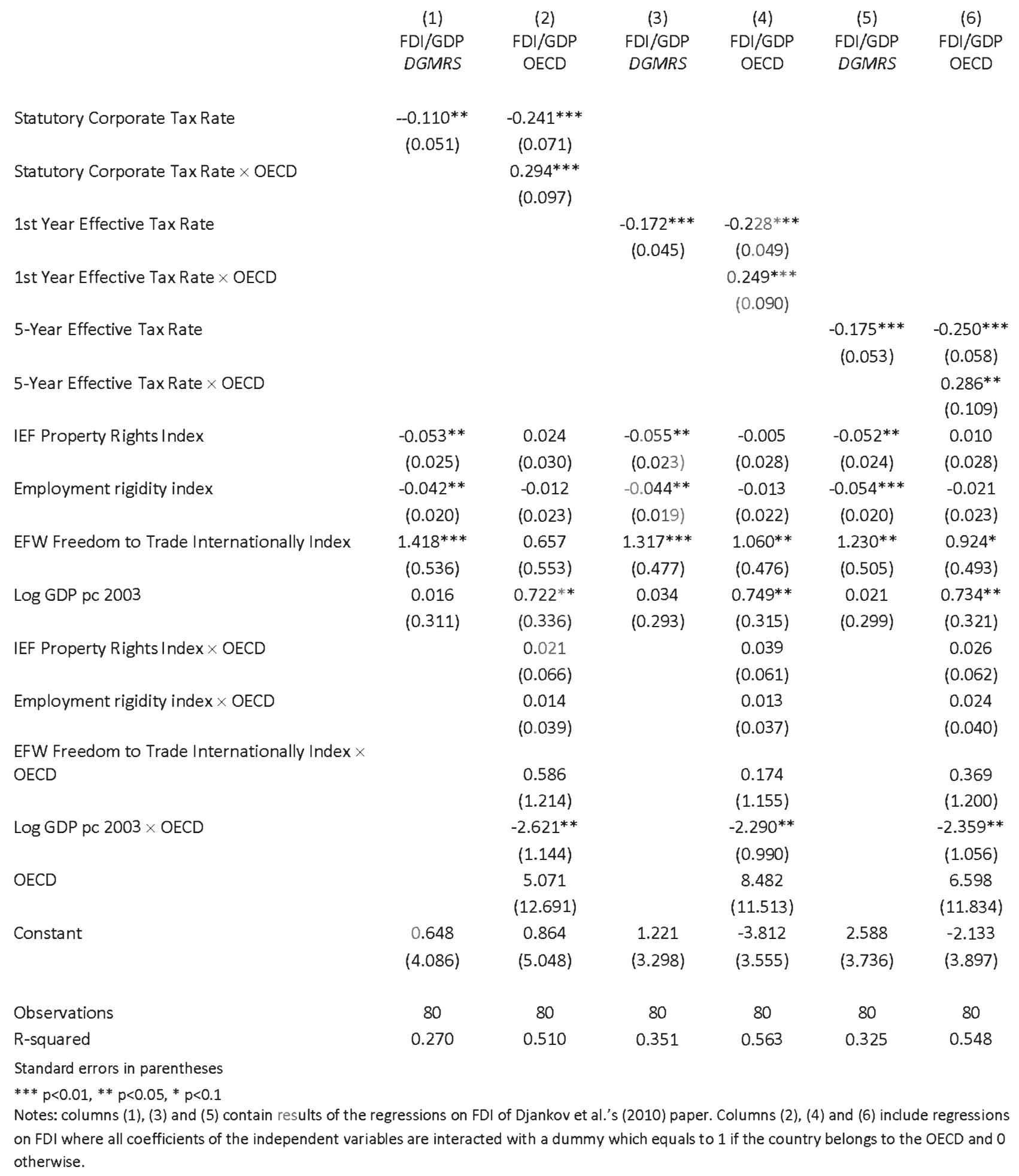

